\title{
GRAMMATICAL ERRORS IN WRITTEN REFLECTIONS OF ENGLISH EDUCATION MASTER'S PROGRAM STUDENTS
}

\author{
Anita Galuh Sri Hapsari \\ E-mail: anitagaluhs@gmail.com \\ Sanata Dharma University, Yogyakarta \\ Aprilia Arnis Ginting \\ E-mail: ginting.arnis@gmail.com \\ Sanata Dharma University, Yogyakarta \\ Barli Bram \\ E-mail: barli@usd.ac.id \\ Sanata Dharma University, Yogyakarta
}

\begin{abstract}
Mastering sentence structure for English Education Master's Program (EEMP) students is obligatory considering their level of education as graduate students, who would become English teachers, lecturers, or researchers in the future. Therefore, major errors in constructing English sentences are no longer expected to happen at this level. This study investigated grammatical errors in sentences produced by EEMP students in their weekly written reflections in their Educational Psychology class. Fifty reflections of the first semester of EEMP graduate students were collected from assignments given by the lecturer of Educational Psychology class. This research employed document analysis as the method and the data analysis was conducted based on error categories. The results showed that the students made 106 morphological errors consisting of omission, addition, alternating form, archi-form, misordering, and 75 syntactical errors, including the use of the subject-verb agreement, preposition, conjunction, punctuation, and parallel structures.
\end{abstract}

Keywords: error analysis; grammatical error; sentence structure; reflection

Abstrak: Penguasaan struktur kalimat bagi mahasiswa Program Magister Pendidikan Bahasa Inggris (MPBI) bersifat wajib mengingat tingkat pendidikan mereka sebagai mahasiswa pascasarjana, yang akan menjadi guru, dosen, atau peneliti bahasa Inggris pada masa depan. Oleh karena itu, kesalahan besar dalam menyusun kalimat bahasa Inggris tidak lagi diharapkan terjadi pada level ini. Penelitian ini menginvestigasi kesalahan gramatikal dalam kalimat yang dihasilkan oleh mahasiswa MPBI dalam refleksi tertulis mingguan mereka dalam mata kuliah Psikologi Pendidikan. Lima puluh refleksi dari semester pertama mahasiswa MPBI dikumpulkan dari tugas yang diberikan oleh dosen mata kuliah Psikologi Pendidikan. Penelitian ini menggunakan analisis dokumen sebagai metode dan analisis data dilakukan berdasarkan kategori kesalahan. Hasil penelitian menunjukkan bahwa mahasiswa membuat 106 kesalahan morfologis yang terdiri 
dari kategori kelalaian, penambahan, bentuk bolak-balik, bentuk archi, salah urutan, dan 75 kesalahan sintaksis, termasuk dalam kesesuain penggunaan subyekkata kerja, kata depan, kata sambung, tanda baca, dan struktur paralel.

Kata kunci: analysis kesalahan; kesalahan gramatikal; struktur kalimat; refleksi

\section{INTRODUCTION}

English Education Master's Program (EEMP) students are categorized as advanced learners or users of the English language. Hence, they are expected to produce correct sentences using appropriate English sentence structures since they are also required to write their final projects or graduate theses in English (Wennyta, 2016). Moreover, as graduate students, they are required to publish their research papers in quality scientific journals. Most of them might become lecturers at higher education institutions, which will require abilities to write grammatically and semantically in English. The students must, therefore, be capable of applying various English rules to construct sentences accurately.

In the present context, it is essential to distinguish a mistake from an error. Brown (2000) says that mistakes and errors are two different phenomena. A mistake refers to a performance error that is either a random guess or a "slip". It fails to utilize a known system correctly. Error is the noticeable deviation from the adult grammar of a native speaker, which reflects the competence of the learner. This research focuses on error analysis. Wu and Garza (2014) define error analysis as a type of approach to analyze speech or written performance of EFL learners. Odin (1989) states that morphological and syntactic errors influence the production of L2 sentence structures. Thus, error analysis is useful to explore errors made by EFL learners in constructing sentences since such errors show a gap in their competence and accuracy in utilizing the language; this kind of analysis becomes a robust instrument to foreign language learning research (Usha \& Kader, 2016). As Ellis and Barkhuizen (2005) say, analysis refers to the process of identifying, describing, and explaining something. Error analysis consists of a set of procedures for identifying, describing, and explaining learners' errors. Corder (1974), as cited in Ellis and Barkhuizen (2005), states that there are five steps in conducting error analysis; collecting the sample of learner language, identifying the errors, describing the errors, explaining the errors, and evaluating the errors. Norrish (1983, p. 7) explains that it is useful to distinguish between different types of inappropriateness in language behavior: the error, the mistake, and the lapse. According to Corder (1967) as cited in Dulay, Burt and Krashen's (1982), an error is reserved for systematic deviations while the learner is still developing knowledge of the second (L2) rule system.

Pedagogically, a reflection facilitates students to think deeply of their previous experiences (Watson, 1996). Students make a reflection to evaluate the process of their learning (Moon, 1993), which is also called a process of metacognition. In line with Watson's (1996) and Moon's (1993) ideas, the EEMP students, who were also the participants of the current research, were asked to write weekly reflections in their Educational Psychology class. The reflection guides were prepared by the lecturer in the form of questions. This research aimed to investigate students' errors, especially in sentence structures in writing their weekly reflections. More specifically, this research attempted to answer the question: What errors commonly occur in English Education Master's Program (EEMP) students' reflections? 


\section{METHOD}

Merriam (2009) says that documents used in the research include anything in existence before the research at hand. Document analysis is a research method used to analyze written or visual materials in textbooks, newspapers, web pages, speeches, videos and any kind of other documents (Ary, Jacobs, \& Sorensen, 2010). The document could give rich descriptive information towards the research. It is supported by Bogdan and Biklen (2003), who say that qualitative researchers are turning to documents as their primary source of data. The current research employed document analysis as the methodology to identify errors in the English Education Master's Program (EEMP) students' sentence structures when writing weekly reflections. The data for this research were collected from the weekly reflections of the first semester English Education Master's Program students of the academic year 2018/2019. The present researchers collected the data from August 25 ${ }^{\text {th }}, 2018$ to September $9^{\text {th }}, 2018$.

Document analysis is part of qualitative research in which the researchers take part in gathering information and examining the data. Therefore, the researchers are considered as the human instruments for such research (Creswell, 2007). There were two instruments applied in this research, namely the current researchers themselves as the human instruments and the students' weekly reflections as the data to examine. Dulay and Burt (1982) classify three types of errors, namely linguistic, surface strategy taxonomy, and comparative taxonomy errors. In this research, the current writers employed the theory of error based surface strategy taxonomy to analyze the data. The students' reflections were examined and categorized into the types of errors based on Dulay and Burt's (1982) theory. Each of the present researchers analyzed the data separately to avoid bias. Once at a time, the researchers met to share their findings in error analysis on the participants' reflections. The researchers worked collaboratively to decide the final results of the examined data.

Every week the students of the English Education Master's Program (EEMP) were assigned to write their after-learning reflections in Educational Psychology class. The individually written reflection was to be submitted online as part of a weekly assignment. The lecturer of this class had prepared six guided questions for the students to elaborate in their reflections, such as: (1) What learning experiences did you get from Tuesday's class?; (2) What difficulties did you find in understanding the required reading materials?; (3) How did group work help you in overcoming those difficulties? Please list the benefits as well.; (4) What may be the drawbacks (disadvantages), if any, of group work in your understanding of the required reading?; (5) What should you do to contribute more to the group work?; (6)What can your lecturer do to help you understand the required reading? The current researchers collected 50 reflections of 25 students to analyze.

The research was conducted in several steps. First, the researchers planned the research on EEMP students' sentence structures as observed in their weekly reflections in the Psychology of Education class. Second, the researchers asked for permission from the lecturer of Psychology of Education to obtain data. Third, after obtaining the data, the researchers analyzed the data based on the proposed theoretical framework on error analysis. Fourth, the researchers wrote the research report.

\section{FINDINGS AND DISCUSSION}

The researchers examined 50 reflections made by 25 EEMP students in the Psychology of Education class. There were 106 morphological errors found in the 
reflections. As presented earlier, Dulay (1982) divides morphological errors based on Surface Strategy Taxonomy into nine types, namely: omission, addition, double marking, regularization, simple addition, misformation, archi-form, alternating form, and misordering. There were five morphological errors found in 50 reflections.

However, not all the reflections which were investigated contained errors. Most of the students made insignificant errors while two of them significantly made errors specifically in a morphological context in their reflection. Table 1 described the total of morphological errors in the fifty reflections examined.

Table 1: Number of Morphological Errors

\begin{tabular}{cccccc}
\hline \multicolumn{2}{l}{ Morphological } & & & & \\
\multirow{2}{*}{ Omission } & Addition & Alternating form & Archi-form & Misordering & Total \\
\hline 50 & 25 & 18 & 7 & 6 & 106 \\
\hline
\end{tabular}

Omissions were mostly found in the students' reflections with the number of errors fifty out of the 106 errors occurred. Some students tended to omit grammatical morphemes, for instance:

Sample 1:

\section{"*Every activity that I do directly I am thinking of metacognition that happen in me."}

The word "happen" was supposed to be added with the suffix "-s" following the singular noun phrase as the noun clause subject "metacognition". The omission occurred when the student constructing the sentence failed to apply the correct verb form by omitting the suffix "-s".

The second frequent errors emerged were additions, in which the students tended to add an unnecessary suffix in a particular word, for example:

Sample 2:

“*We take a parts as a self reminder to each other, if there are some assignments that we have to discuss and work together."

The word "parts" should be "part' (as a singular noun), without the suffix "-s". The addition happened when the student added the suffix "-s" to the word "part" that was supposed to be a singular form.

Altering form as the third common error occurred when the student gives "a way to the fairly free alternation of various members of a class with each other" (Dulay, 1982), for example:

Sample 3:

"*First, in my opinion, the amount of reading is still too many to read in a short time. My group members gave much benefits to me."

In sample 3 the alternating form occurred when there was a change in the determiner modifying the uncountable noun "reading". The use of determiner "many" 
did not fit the noun in the sentence. Meanwhile, the alternating form in the second sentence happened when the student failed to recognize that the noun "benefits" was plural and countable; the student used the determiner "much" instead.

Sample 4:

"*It gave me benefits to understand more for that calculation and matrix, this activities also gave me a good relationship to my group member also."

Archi-form commonly happened when the student put the wrong determiner as a demonstrative adjective to describe the noun. In sample 4, the student applied the determiner "this" for the plural noun "activities" which was inappropriate with English grammar rules. The student must have used "these" to meet the English grammar requirement.

Misordering was the fifth common error found in the students' reflection. It occurred when the students misplaced a morpheme or group of morphemes in an utterance, for example, "*I wonder if "which should be" is there...I wonder if there is..." and "to do not abandon" which should be "not to abandon". Sample 5 showed an example of this kind of error.

Sample 5:

"*When I wonder if is there any possibility to use metacognition to young learners, I read the third required reading. I read all my stick notes in my wall to do not abandon myself to despair and to always remember my parents about their effort for me to study here."

Besides morphological errors, some of the EEMP students also made mistakes in the syntactical error category. In the current research, the syntactical errors are categorized into five categories, namely subject-verb agreement, preposition, parallelism, punctuation, and conjunction.

Table 2: Number of Syntactical Errors

\begin{tabular}{cccccc}
\hline Syntactical & & & & & \multirow{2}{*}{ Total } \\
\hline S-V Agreement & Preposition & Parallelism & Punctuation & Conjunction & \\
\hline 32 & 13 & 12 & 11 & 7 & 75 \\
\hline
\end{tabular}

Based on the data analysis, 75 syntactical errors were occurring in the students' reflections; the most frequent syntactical errors happened was the use of the English language subject-verb agreement.

Subject-verb agreement is the fundamental or minimum requirement in constructing sentences, especially in the English language. Some students failed to include the predicate while constructing a sentence. Sample 6 is an example of a mistake. 
Sample 6:

"*My plan and strategies to improve my understanding of the next meeting materials. Read and re-read the materials, to get the better understanding, search the other materials to increase the interpretation of the materials."

When the student wrote "*My plan and strategies to improve my understanding of the next meeting materials..." he or she did not use any predicate to construct a sentence. The sample sentence showed the student's failure to make a correct English sentence since there was no verb or to be, which functioned as the predicate (finite verb). Hence, it could be stated that the bold part in sample 6 was not a sentence; it was a phrase.

There are several verbs which precede fixed prepositions or which take no preposition at all. Some verbs that should be directly followed by an object. Unfortunately, some students still made mistakes by combining the verb and preposition. Sample 7 provided an example of this kind of error.

Sample 7:

"*I asked to my friends to explain for me about that terms."

As seen in sample 7, the student applied the preposition "to" after the verb "asked" and "for" after the verb "explained" while those verbs should be directly followed by objects.

Parallelism was also included in the error issue occurring in the EEMP students' written reflections. It happened when the students failed to use the words that were supposed to be in the same class. Sample 8 showed the student's failure to use a parallel structure.

Sample 8:

"*Since my family support me, with my metacognitive awareness, through hard work, work smart and being consistent; I can be educated person and able to change my family level."

In sample 8, the student should apply a parallel structure in the bold phrases, such as "hard work, smart work, and consistency" instead of mixing the word class.

The error that also occurred in the students' writing was the misuse of punctuation. As a part of the minimum requirements in constructing an English sentence, the use of punctuation should be considered.

Sample 9:

"*So I know the progress of my learning and able to strengthen my weakness."

Sample 9 showed the absence of a comma as the punctuation that should be put after the conjunction "so". It might not change the meaning of the sentence but it must be disturbing and was considered wrong in a certain context. 
The last error discussed in this paper was the use of conjunctions. Based on the written English rule, conjunction occurred in the sub-clause which cannot stand alone without the main clause. Sample 10 gave an example of this kind of error.

Sample 10:

"*And I should play my roles to develop the metacognitive environment, be it in campus or at home, by encouraging more metacognitive activities in my learning process."

Note that researchers who have conducted error analysis claimed that errors are not influenced by their first language but it is influenced by their common learning strategies (Yang, 2010). Hence, lecturers need to set their strategies in helping the students to minimize errors in their reflection writing. Structural errors are sensitive to translate the meaning of the sentences (Weng, Huang, \& Ahuja, 1989). Errors can be the parameters of student language mastery. This study suggests that teachers should conduct error analysis of students' work. Rostami and Boroomand (2015), as cited in Dweikat and Aqel (2017), state that analyzing EFL errors in their written tasks make lecturers more aware of the types of errors. This analysis, moreover, can be the basic reason for lecturers to create more effective teaching with appropriate methods and techniques to help students in dealing with grammatical errors.

Regarding the types of grammatical errors made by the students, they can be categorized into two types of grammatical errors; these grammatical issues are also referred to as the second language students' errors in writing (Myles, 2002; see also Mulatsih, 2018). The first category includes errors at the morphological level. According to Dulay, et al. (1982), one of the common errors at morphological level made by EFL learners is error types based on Surface Strategy Taxonomy, which highlights the ways surface structures are altered. In this case, learners may omit necessary items or add unnecessary ones; they may mis-form items or mis-order them. The errors based on this type are presented as follows.

a. Omission: The absence of an item appearing in a well-formed utterance can be called an omission error. Language learners omit grammatical morphemes much more frequently that content words, as in: "*He eat banana" should be "He eats a banana" or "He eats bananas".

b. Addition: Addition errors are the opposite of omissions. The characteristic is the presence of an item which must not appear in a well-formed utterance, as in: "* I have to eating" should be "I have to eat".

c. Double Marking: When the learners fail to debate certain items, which are required in some linguistic constructions, but not in others, they make errors called double marking, as in: "*I did not went" should be "I did not go".

d. Regularization: The learners employ the rules that are used to produce the regular ones to those that are irregular. It happens to verbs and nouns, for example, the students write "*deers" for the plural form of "deer" that should be "deer" (the same as for the singular form).

e. Simple addition: Simple addition errors are the use of an item which should not emerge in a well-formed utterance but they are neither double marking nor regularization.

f. Misformation: It is characterized by the use of the wrong form of the morpheme or structure. In misformation errors, the learner employs something although it is 
incorrect, as in: “*The dog eated the chicken". It should be "The dog ate the chicken".

g. Archi-form: The selection of one member of a class of forms to stand for others in the class is a common characteristic of all stages of second language acquisition. It is called an archi-form; for example, a learner may temporarily choose just one of the English demonstrative adjectives this, that, these, and those, as in That dog - these dogs - those dogs

$h$. Alternating form: As the learners' vocabulary and grammar develop, the use of archiforms often gives way to the fairly free alternation of various members of a class with each other. In the case of pronouns, we can see:

Masculine for feminine (or vice versa), as in $\rightarrow$ he for she

Plural for singular (or vice versa), as in $\rightarrow$ they for it

Accusative for nominative case (or vice versa), as in $\rightarrow$ her for she

$i$. Misordering: Incorrect placement of a morpheme or group of morphemes in an utterance is a characteristic of misordering, as in: "* I do not know what is that" should be "I do not know what that is."

The second category includes errors in the syntactic level (Myles, 2002). Several researchers have already conducted error analysis from a variety of perspectives to see errors in several units of language. Sermsook, Liamnimitr, and Pochakorn (2017) researched on error analysis on written English sentences of Thai EFL students. The results showed there were 35 errors in subject-verb agreement occurring in 104 students' writing assignments; it showed that subject-verb agreement was ranked the third among all errors found.

Another common error that happens in EFL learners is the use of parallelism. Frazier, Taft, Roeper, Clifton, and Ehrlich (1984) conducted error analysis on the parallel structure and found that the misuse of parallel structure dragged ambiguity to understand the whole meaning of the sentence. Kraichoke's (2017) research showed that students potentially made mistakes in using prepositions in their writing. Uibu and Liiver (2015) mentioned "Learning grammar, especially the use of punctuation marks is one of the most difficult tasks for students. This is confirmed by international comparative studies." Sermsook, Liamnimitr, and Pochakorn (2017) found that the use of comma (,) and period (.) were problematic for Thai students in using English. Moreover, the omission of comma (,) also potentially happened in EFL learners (Kraichoke, 2017). Another important language unit that should be correct in the use is a conjunction. The use of conjunction in students' writing is essential since it affects the quality of their academic writing, especially for postgraduate students (Swales \& Feak, 2005).

\section{CONCLUSION}

The research results showed that there were still problematic issues in the EEMP students' weekly reflections. The current study found 181 errors in morphological and syntactical units, 106 morphological errors and 75 syntactical errors. The number of omissions in morphological errors appeared the most frequent among the other four morphological errors while in the syntactical category, the misuse of the subject-verb agreement occurred the most frequently among the categories. The students still made mistakes in their sentences in the reflections, especially mistakes in the morphological category, such as omission, addition, alternating form, archi-form, and misordering. Several EEMP students tended to make errors in syntactical levels, such as in the use of the subject-verb agreement, prepositions, parallel structure, punctuation, and 
conjunctions. The research results can be the data for the EEMP stakeholders to improve students' capability in writing and to minimize grammatical errors - to reduce ungrammaticality.

\section{REFERENCES}

Ary, D., Jacobs, L.C., \& Sorensen, C. 2010. Introduction to Research in Education (8th ed.). Belmont, CA: Wadsworth.

Bogdan, R.C. \& Biklen, S.K. 2003. Qualitative Research for Education: An Introduction to Theory and Methods (4th ed). New York: Pearson Education.

Brown, H.D. 2000. Principles of Language Learning and Teaching (4th ed). New York: Longman.

Creswell, J.W. 2007. Qualitative Inquiry and Research Design: Choosing among Five Approaches. Thousand Oaks, CA: Sage Publications, Inc.

Dulay, H., Burt, M., \& Krashen, S. 1982. Language Two. New York: Oxford University Press.

Dweikat, K. \& Aqel, F. 2017. A longitudinal Analysis Study of Writing Errors Made by EFL Students at Al-Qud Open University (QOU): The Case of Language Use Course. British Journal of Education, 5(13), 127-145. Retrieved from www.eajournals.org.

Ellis, R. \& Barkhuizen, G. 2005. Analysing Learner Language. New York: Oxford University Press.

Frazier, L., Taft, L., Roeper, T., Clifton, C., \& Ehrlich, K. 1984. Parallel Structure: A Source of Facilitation in Sentence Comprehension. Memory \& Cognition, 12(5), 421-430.

Kraichoke, C. 2017. Error Analysis: A Case Study on Non-native English Speaking College Applicants' Electronic Mail Communications (Master's thesis). Retrieved from http://scholarworks.uark.edu/etd/1910.

Merriam, S.B. 2009. Qualitative Research: A Guide to Design and Implementation. San Fransisco, CA: Jossey-Bass.

Moon, J. 1999. Learning Journals: A Handbook for Academics, Students and Professional Development (2nd ed). New York: Routledge.

Mulatsih, M. 2018. The Effectiveness of Grammar Tutoring Program Based on Students' Feedback Batch 2016 ELESP. LLT Journal: A Journal on Language and Language Teaching, 21(2), 175-182. Retrieved from http://ejournal.usd.ac.id/index.php/LLT/article/view/937

Myles, J. 2002. Second Language Writing and Research: The Writing Process and Error Analysis in Student Texts. The Electronic Journal for English as a Second Language, 6(2), 1-20. Retrieved from http://www.teslej.org/wordpress/issues/volume6/ej22/ej22a1/?wscr.

Norrish, J. 1983. Language Learner and Their Errors. London: The Macmillan Press.

Odlin, T. 1989. Language Transfer: Cross-linguistic Influence in Language Learning. Cambridge: Cambridge University Press.

Sermsook, K., Liamnimitr, J., \& Pochakorn, R. 2017. An Analysis of Errors in Written English Sentences: A Case Study of Thai EFL Students. English Language Teaching, 10(3), 101-110. https://doi.org/10.5539/elt.v10n3p101.

Swales, J. \& Feak, C. 2005. Academic Writing for Graduate Students: Essential Tasks and Skills. The Electronic Journal for English as a Second Language, 8(4), 1-2. Retrieved from http://www.tesl-ej.org/wordpress/issues/volume8/ej32/ej32r1/. 
Uibu, K. \& Liiver, M. 2015. Students' Grammar Mistakes and Effective Teaching Strategies. International Journal of Teaching and Education, 3(1), 70-87. https://doi.org/10.20472/TE.2015.3.1.006.

Usha, P. \& Kader, N.A. 2016. Syntactic and Morphological Error Analysis in English Language among Secondary School Students of Kerala. IOSR Journal of Humanities and Social Science, 21.

Watson, J. 1996. Reflection through Interaction: The Classroom Experience of Pupils with Learning Difficulties. London: The Falmer Press.

Weng, J., Huang, T., \& Ahuja, N. 1989. Motion and Structure from Two Perspective Views: Algorithm, Error Analysis, and Error Estimation. IEEE Transection on Pattern Analysis and Machine Inteligence, 11(5), 451-476.

Wennyta. 2016. An Analysis of Grammatical Errors Present in Final Project Proposal Made by English Study Program Students of Batanghari University Jambi. Jurnal Ilmiah Dikdaya, 6 (2). Retrieved from http://dikdaya.unbari.ac.id/index.php/ dikdaya/article/view/8.

Yang, W. 2010. A Tentative Analysis of Errors in Language Learning and Use. Journal of Language Teaching and Research, 1(3), 181-193. 